\title{
Faculty Perceptions of the Importance of Media Education in Building up Students' Dispositions in the
} Arab World

\author{
Mahmoud Hamid Al Migdadi ${ }^{1, *}$ \\ ${ }^{1}$ Department of Administration and Foundations of Education, Faculty of Educational \\ Sciences, Al al-Bayet University, Mafraq, Jordan \\ *Correspondence: Department of Administration and Foundations of Education, Faculty of \\ Educational Sciences, Al al-Bayet University, P.O. Box: 130040 Mafraq, 25113, Jordan. Tel: \\ 962-796-57-9412. E-mail: malmigdadi@yahoo.com
}

This work has been carried out during sabbatical leave granted to the author (Mahmoud Hamid Almigdadi) from Al Al-Bayt University during the academic year 2017/2018

Received: January 29, 2018 Accepted: February 20, 2018 Published: March 19, 2018

doi:10.5296/ije.v10i1.12551ＵRL: https://doi.org/10.5296/ije.v10i1.12551

\begin{abstract}
The purpose of this study is to investigate the perceptions of faculty members at $\mathrm{Al}$ al-Bayet University regarding the role of media education in building up students' dispositions. The study further examined the impact of the variables of gender, type of college and years of experience on participants' responses. This study used the quantitative research methodology. The study population consisted of all faculty members, 316 male and 88 female. A total of 252 faculty members completed and returned the questionnaires. The results of the study have revealed that media education plays an important role in building up the cognitive, the affective, and the behavioral components of the students' dispositions. While no statistically significant differences were found due to gender and type of college, there were differences due to years of experience in the participants' responses. Based on the results of the study, several recommendations were offered, including conducting seminars and workshops for faculty members, conducting more studies on media education and its impact on teaching learning process, and integrating a course in media education within the curricula of universities.
\end{abstract}

Keywords: media education, faculty members, Al al-Bayet University, students' dispositions 


\section{Introduction}

The rapid and increasing changes in the domains of politics, economy, and culture that human societies are witnessing in the present age have posed great challenges that must be met in order to adapt to these changes and keep abreast of the scientific, technological and civilizational developments in these domains. In the midst of these changes, each society, however, attempts to preserve its culture i.e. its value systems, traditions and beliefs, characteristics, modes of living and its peoples' rights. It also realizes the need to sensitize its generations to the importance of dialogue and openness with the other. In this context, education and educational institutions, especially universities, are of great importance and valuable contribution. It is, therefore, necessary to focus on improving the quality of the teaching and learning processes in all educational institutions, and particularly so in universities.

Going through the history of universities in the world, one realizes that their roles at the beginning were not so far from the schools' roles in terms of focusing on the cognitive aspect of the learner's personality, i.e., the students' intellectual abilities. As such, their main aim was to transfer knowledge to learners, through stuffing a huge amount of information into their heads and filling their minds with difficult definitions and facts, due to their importance on the one hand and as the sole objectives that universities seek to achieve on the other hand (Shamany, 2014).

Learners then had negative roles; they were receipts of knowledge and learnt about facts and skills. They used to listen to their teachers, absorb and repeat what is given to them by the teachers, without having the chance to verify its validity or judge its accuracy. What learners need, then, was to master knowledge in various ways and means, even if it is not in line with their needs, interests, attitudes and abilities on the one hand, and even if it is not linked to their daily lives and social problems on second hand.

The efforts of scientists and educators, however, have resulted in emerging ideas and educational theories that quickly changed the status of education, and hence the role of schools and universities in attaining the outcomes of the teaching learning process. The roles of these educational institutions are no longer limited to providing the students with academic and cognitive skills, but rather, to help in the development of their total dispositions in a comprehensive, balanced and integrated manner (Brophy, 1999; Dollard and Christensen, 1996; Shamany, 2014).

Helping learners fulfill their potential and preparing them for a satisfying and productive life through facilitating the process of learning and the acquisition of knowledge, skills, attitudes, beliefs, and values are, among many others, the basic functions and primary purposes of education (Peifer, 2014). Now, learners have active roles. They become lifelong learners, learning anywhere and anytime. They search for or even create knowledge and learn how to create new things and find new applications. These functions in the present age may enhance participation in an information rich society, where knowledge is regarded as the main source for socio-cultural and politico-economical development of countries and nations. Information 
rich societies are developed and dominating and they are controlling the information throughout the world (Hussian, 2005).

In the era of information explosion, the media has remained the major source to deliver knowledge and information. The Business Dictionary defines media as "communication channels through which news, entertainment, education, data, or promotional messages are disseminated. Media includes every broadcasting and narrowcasting medium such as newspapers, magazines, TV, radio, billboards, direct mail, telephone, fax, and internet. The media is ubiquitous and immensely powerful and has been considered a major agent of socialization for today's children. With technological advancements, the media has penetrated into the lives of the new generation. Apart from traditional media like television and the radio, the Internet has become one of the most influential media. Indeed, the Internet is not exactly a new media to the new generation. They, in the words of (Tapscott, 1998) literally "grow up digitally" or, to be more precise, are "born digitally." (Chu, \& Chu, 2010).

In general, mass media are the result of the people's need to satisfy such requirements as gaining news and information, entertainment, and socialization (Ulaş, Epçaçan and Koçak, 2012). The main feature of the current century is media-saturated culture and provision and ease of access to different types of media for everybody, particularly children and adolescents (Potter, 2008; Wan \& Gut, 2008).

The recent increase in use of digital devices such as laptop computers, iPads, and web-enabled cell phones has generated concern about how technologies affect student performance (Duncan and Wilcox, 2012). The information age becomes an era of knowledge providing sound and unmatched feasibility for discovery, exchange of information, communication and exploration to strengthen the teaching learning process (Hussain, and Safdar, 2008). Hence, the need for the integration of media literacy in the teaching and learning process has become evident, particularly if our learners to become well equipped with the twenty first century skills.

\section{Statement of the Problem}

Going through the educational movement in its forms and stages in the present age, one can find that there are three main domains of the educational goals, namely, cognitive, affective, and behavioral. Any deficiencies in addressing these domains will lead to the presence of an incomplete or unbalanced personality. Universities play a vital role in building up students' dispositions through the teaching and learning process. This can be five specific ways. First, they bring the desirable change in the behaviors of students in all those three domains, i.e., cognitive, affective, and behavioral. Second, they help students acquire knowledge, skills, applications, attitudes, and interests. Third, they attain proper growth and development of students' dispositions in various spheres, namely physical, mental, emotional, social, moral, aesthetic, and language. Fourth, they help students get adjusted to themselves and to the environment; and fifth, they help students realize their goals of life (Mangal, 2011).

Educators have pointed out the importance of fun and entertainment in the learning process. 
Prensky (2002), for example argued that fun and learning go hand in hand. This is because, fun creates relaxation and motivation, where relaxation enables learners to take things in more easily, and motivation enables them to put forth effort without resentment. In the words of Marshall McLuhan "Anyone who makes a distinction between education and entertainment doesn't know the first thing about either." (Prensky, 2002). Fortuna (2015) argues that sports media literacy, due to its authenticity and relevance, can be a model for traditional literacy classrooms as ways to infuse multimodal texts and help students to gain both enhanced communication skills and critical distance from media rhetoric. Exploiting new technologies in teaching and learning in the classroom enhances students' language and literacy skills, general academic success, and enhancement of their working, living and being productive citizens in the realities of the current digital age (Jia, Snow, and White 2015, Kivunja, 2015). UNESCO defines media education literacy as the priority field of the cultural educational development in the twenty first century; however, media education is still not equally spread in all of the European, African and Asian countries (Fedorov, 2014).

Observation has shown that many educational stakeholders and policymakers in Jordan do not seem to appreciate the importance and roles of media education in the process of teaching and learning, and thus in building up students' dispositions. Some education professionals seem to show tepid attitudes towards the integration of media education into university curriculum. It is based on this premise that the researcher is trying to investigate the perceptions of the faculty members towards the importance of media education in building up university students' dispositions.

\section{Importance and Purpose of the Study}

The significance of this study emanates from the issue it addresses, namely, the faculty perceptions of the importance of media education in building up students' dispositions. This area of research has received very little attention. No studies were found in the Arab World universities in general or in Jordanian universities in particular. Therefore, this study seeks to add to the literature new information regarding the perceived importance of media education in building up students' dispositions at tertiary education.

The general objective of the study is to identify the importance of media education in building up students' dispositions through examining the perceptions of $\mathrm{Al}$ al-Bayet University faculty members, and the impact of some demographic variables on this issue. This will help provide a clear picture of the faculty members' experiences, attitudes and perceptions regarding the role of media education in the teaching and learning process, which will lead to the development of suggestions that will help to integrate media education courses and programs that serve students' needs to achieve effective and meaningful learning.

\section{Research Questions}

This study attempts to investigate the following questions: 
1- What are the roles of media education in building up the cognitive, affective, and behavioral components of the university students' dispositions from the perceptions of Al al-Bayt University faculty members?

2- Are there any statistically significant differences in the responses of the participants about the roles of media education in building up university students' dispositions due to the variables: gender (male, female), years of experience (less than five years, from five to ten years, more than ten years), and type of college (natural and applied sciences, humanities)?

\section{Assumptions of the Study}

The assumptions of this study include the following:

- It is assumed that the faculty members at Al al-Bayet University appear to have willingness to express their perceptions towards the importance of media education in building up students' dispositions.

- It is assumed that the responses given by the participating faculty members are honest and accurate because the anonymity and confidentiality were emphasized.

- It is assumed that using Arabic for the purpose of this study will facilitate the faculty members' comprehension of the questions, make them concentrate on their thoughts, and ease their anxiety. Hence, the questionnaire was written in both English and Arabic with the hope that faculty can provide more relevant responses.

\section{Limitation of the Study}

The following limitations are inherent in this study:

- The study only involved the faculty members of Al al-Bayt University during the first semester of the academic year 2017/2018. Hence, the findings of the study are only generalized to instructors of $\mathrm{Al}$ al-Bayt University.

- Considering the English competence of the faculty members in some colleges, the questionnaire was in a combination of Arabic and English. It should be brought to mind that there can be no exact equivalents of Arabic terms and expressions in English. However, the essence of the message is maintained.

\section{Background of the Study}

\subsection{Cognitive, Affective and Behavioral Domains}

The ultimate goal of education is all round development of the individual, and the desired outcome of the learning process is to have the greatest degree of whole person learning. 
Learning can be viewed as a combination of intellect, emotion, and physical skills. It is associated with behavioral changes in the cognitive, affective (attitudes and feelings) and behavioral domains (Farrant, 1980). As such, the educational process should function in integrative and interactive manner, combining the affective and behavioral dimensions with the cognitive domain always found in the process. Each of the three domains functions both independently and interdependently to certain degree. According to Hoover (1974, as cited in Micklich, 2011: 264-265) “ in order to develop a conceptualization of experiential learning that is useful experimentally, experiential learning practitioners need effective delineation and definition of the cognitive, affective and behavioral (behavioural) domains of learning as separate components. At the same time he also stated that, "the learning dimensions of cognition, affect, and behavior are combinatorial, co-existent and perhaps even synergistically interactive.

Further, these domains are connected, and the condition of one influences the others. The attainment of a responsible student is the result of the functioning of his whole personality; therefore, apart from assessment of the cognitive domain, the affective and behavioural domains must also be given paramount place when assessing learner's outcomes (Eshun, \& Mensah, 2013: 187). That is to say, the assessment of students' learning has to be carried out in holistically; in all activities in the cognitive, affective and behavioral domains.

Each of the three domains requires specific considerations, based on the intended learning objectives (Main, 1992). These three domains can be taught of as the objectives of the instructional process. The cognitive domain objectives produce outcomes that focus on knowledge, facts, mental skills and abilities requiring memory, thinking, understanding, problem solving, and reasoning processes. This domain mainly emphasizes remembering or reproducing information, which have been learnt. The affective domain objectives produce outcomes that focus on feelings, interests, attitudes, dispositions and emotional states. It also deals with behavioral aspects, attributes, beliefs and values. Finally, the behavioral domain objectives produce outcomes that focus on motor skills and perceptual processes. It deals with manipulation of materials and objectives (Nitko and Brookhart, 2001; Martin, 2006),

Although, the three domains have different explanations, they are closely related in two ways: first, single major objective can involve learning in two or even all three domains and second, attitudinal development may even precede successful learning in the other domains (Eshun, \& Mensah, 2013). According to Micklich (2011) the relationship between the affective domain and learning is central to every part of the learning and evolution process. He argues that there are two points of consideration in this relationship. First, threshold of consciousness, where the awareness of the stimulus initiates the learning process, and second threshold of evaluation, where the willingness to respond is the basis for behavioral responses without which any evaluation of the learning process can take place. Hence, the affective domain provides the link between the stimulus and the cognitive and behavioral aspects of an individual's personality, or the sum total of their values and beliefs and the extent to which they show them.

Behaviour is a culmination of the cognitive and affective domains. From a behavioral 
perspective, these domains are effectively measured not by a single, but by a series of experiential exercises over time, where they fully contribute to skill development. So, in order to determine if cognition is correct, one can judge through the behavioral domain (Micklich, 2011).

\subsection{What is Media Education?}

The first systematic description of media education was given in the seventies of the twentieth century. At a meeting of member organizations held in June 1973, the United Nations Educational, Scientific and Cultural Organization (UNESCO), posited the following definition: "Media education is the study, learning and teaching of, and about, the modern media of communication and expression as a specific and autonomous area of knowledge within education theory and practice, distinct from their use as aids for the teaching and learning of other areas of knowledge, such as mathematics, science and geography" (IFTC, 1977: 3).

In 1978, the Finnish researcher Sirkka Minkkinen pointed out that the goal setting for mass media education is aimed at embracing aesthetic, communicative and social approaches (Tufte, 1999). Thoman (1995 in Chu \& Chu, 2010: 4) suggests that media literacy is a study of the mass media for increasing people's critical understanding of 'what' mass media are and 'how' they work and produce meaning.

According to the National Association for Media Literacy Education (NAMLE, 2010: 1), media literacy consists of a series of communication competencies, including the ability to access, analyze, evaluate, and communicate information in a variety of forms. Ofcom, (2010: 1) defines media literacy as: "The ability to access, understand and create communications in a variety of contexts." Buckingham (2003) considers media education as the process of teaching and learning about the media.

In Canada, the Media Literacy Week - November 6-10/2017, gave the following definition: "Media education is the process through which individuals become media literate - able to critically understand the nature, techniques and impacts of media messages and productions. In Hong Kong, media literacy is defined as a life skill that enables young people to critically understand, analyze, use and influence the media (Lee, 2010: 3).

Lee \& So (2014: 138) argues that although the definitions of media education look different, they address similar purposes, including critically engaging with media messages and increasing the ability to access, understand, analyze, use, and create media products.

\subsection{Media Education around the World}

The countries of the world differ in their interactions with media education. Developed countries, such as Canada, and most of Europe have established the foundations of media education and its general guidelines and curricula. In these countries, there are established and systematic approaches towards media education. They have also prepared and trained teachers, and provided educational resources to teach media education in their educational institutions. Countries, such as Italy and Ireland, have media education at their schools, but in 
a non-systematic and irregular or incomplete manner. Finally, countries where media education is still in the category of non-school education, where it is provided in youth programs, women's groups, places of worship. These countries include the United States of America, and third world countries. Among the Arab countries, Lebanon is teaching students five classes entitled (Media Education) within the subject of national education and socialization in the first grade intermediate, and also offers of third grade students of secondary schools four classes within the same subject matter entitled (Media and public opinion) (Shomaimari, 2010: 22).

The first movements in media education were made in 1920s in France. The media education in Great Britain and Russia is also old, dating back to 1920s. Nowadays media education became important in many countries. Along with Britain, France still remains one of the most active European countries to develop the media and ICT education. Recently quite a few books, collections of articles textbooks and other publication have been published in Great Britain, and translated into foreign languages. Schools in Germany began their media education practice with its integration into the required curriculum and media culture is taught in the majority of German universities. Canada, Australia and USA have a developed media education. In spite of the difficulties in the 1990s, media literacy has good prospects in Russia. We can also see the fast progress of media education in other Eastern European countries. Hungary became the first European country to introduce obligatory media education courses in secondary schools (Fedorov, 2008).

In the Arab world, the idea of media and digital education began during the first decade of the third millennium and came as an urgent necessity and a goal to increase knowledge through analysis and criticism of the media text, whether provided by Arab or foreign media. The Arab University of Beirut is the starting point for this new concept. The first Arab media workshop was launched in 2006 in the context of the globalization of media and the age of communication and information technologies and their impact on changing many social and intellectual concepts of citizens and society (Al Badrani, n.d.; Shomaimari, 2010).

In Jordan, Al al-Bayet University is currently working on the integration of media education in its curriculum. In collaboration with UNESCO, the University will be the pioneering institution to produce a media education course at the university level.

Al al-Bayet University has, since its establishment in 1994, strived to become one of the foremost institutions of higher learning in all domains of knowledge not only in the country but the region as a whole through training its students not only to achieve academic distinction but also ethical, moral and spiritual excellence. On the philosophical level, the university earnestly tries to instill in its students integrity, dignity and honour in order to produce students who are morally and spiritually upright in their conduct as good citizens of the country and who are willing to contribute to the betterment of their society as well as the Muslim world at large. Moreover, on the intellectual level, Al al-Bayt University aspires to bring forward students who are highly intellectual and professional to move the nation forward to greater heights of progress on par with the rest of the developed nations (Almigdadi, 2008). 


\section{Relevant Research}

This section provides information about some studies and researches that have been carried out related to the problem of the present study. The studies are arranged chronologically from most recent to oldest.

Tur, Marin and Carpenter (2017) conducted a study to examine student teachers' use and perceptions of Twitter, based on a mixed-method comparative approach. The participants $(n=153)$ were education majors who used Twitter as a part of required coursework in their programs at two universities in Spain and the United States. The theoretical background covers research on international work carried out on Twitter as well as a brief overview of the introduction of technology in two national educational systems. Quantitative data were collected via a survey, while qualitative data were obtained from students' reflective written texts. The majority of participants from both contexts perceived educational benefits to Twitter. However, their use of Twitter, and the nature of their perceptions of its educational value, appeared to differ in important ways. The USA participants' longer and more frequent use of Twitter was accompanied by more positive beliefs regarding the educational relevance of Twitter. While many Spanish participants saw value in the use of Twitter to find and share information, USA students highlighted interactive and collaborative uses. The study uncovers some challenges for learning related to Twitter's short format. In the conclusion section, the researchers discuss implications for learning and teaching in an age of ubiquitous social media.

Maghazi (2015) surveyed education and media specialists to determine their views on including media education in the Palestinian curriculum in terms of its importance, objectives, content and methods. The research was applied to a random sample consisting of 136 faculty members of education and media departments at the Islamic, Al-Azhar and A1 - Aqsa Universities. The research has included three variables, namely specialization, academic degree, and experience. The researcher used a questionnaire consisting of 33 items organized into four themes: The importance of media education, its objectives, content and methods. The researcher came up with significant findings: The items regarding the including media education in the curriculum came within the rating "strongly agree". There were no statistically significant differences between the rating averages of education specialists and media specialists concerning the inclusion of media education in the Palestinian curriculum. There were significant differences in the rating averages of specialists concerning the inclusion of media education in the curriculum with regard to its importance, objectives, content and methods due to the variables of both academic degree and experience.

Muhingi, Mutavi, Kokonya, Simiyu, Musungu, Obondo, \& Kuria (2015) conducted a study that aimed at establishing the relationship between secondary school students' access to and use of social network sites at an Open Learning Centre in Kenya. The study sought opinions of key informants, parents, teachers and policy-makers in Kenya at the school compound. In addition, it investigated the behavior of the students to generate both quantitative and qualitative data. Findings in this study showed that secondary school students in Kenya were much more vulnerable to the adverse effects of social networks in a manner consistently and 
concurrently similar to that found elsewhere in the worldwide. This included conversion of academic into recreational sessions and subsequent poor academic performances among the majority of the secondary school students in Kenya.

Bani Issa and Al Fawaris (2015) conducted a study which aimed at revealing the Islamic media, and its impact on the educational process. The study was divided to three subjects; first, the concept of the Islamic educational media, and its impact on the construction of balanced human personality. The Second subject viewed its role in activating the educational role of different institutions. Finally, it discussed the role of Islamic educational media in achieving the development of Muslim nation. As for the conclusion, it indicated the most significant findings and recommendations. The results of the study revealed that Islamic educational media contributes in building a humanitarian balanced personality. The results also showed that Islamic educational media contributes in directing various institutions in carrying out their educational roles. Finally, the results showed that Islamic educational media contributes in achieving of the advancement of civilization of the Muslim nation.

Jia, Snow, and White (2015) conducted a study to identify urban adolescents' perspectives on the use of technology within teen culture, for learning in general and for literacy instruction in particular. Focus group interviews were conducted among linguistically diverse urban students in a lower income neighborhood in the Northeastern region of the United States. The major findings of the study were that, firstly urban teens primarily and almost exclusively used social media and technology devices for peer socializing; secondly, they were interested in using technology to improve their literacy skills, but did not appear to voluntarily or independently integrate technology into learning. These findings lead to suggestions for developing effective literacy instruction using new technologies.

Jaidori (2014) conducted a study which aimed to identify the impact of educational media represented by the role of the Satellite Educational Syrian Chanel in the development of the performance of students in both educational and cultural aspects. The sample is the opinions of students taken from the city of Damascus. The researcher designed a questionnaire consisted of 20 items distributed on educational and cultural aspects. The sample of the study consisted of 800 students who were selected randomly from the 10,200 students in the city of Damascus. After applying the study tool on the sample and conducting statistical necessary treatments, the results of the study showed the approval of members of the sample to a large extent on the impact of media education in the development of their performance at the educational and cultural levels. The results showed no statistically significant differences in the viewpoints of students about the impact of media education in their performance on the educational and cultural levels due to the variables of gender and major.

Duncan, Hoekstra, and Wilcox (2012) conducted a study to assess the effects of technology use (laptop computers, iPads, and web-enabled cell phones) on student attitudes and learning. Data were gathered in an introductory science courses at a major university through combining observations, survey, and interviews. The results showed a significant negative correlation between in-class phone use and final grades. While $75 \%$ of students reported regular cell phone use, observation suggests undergraduates typically underreport the 
frequency of their in-class use of digital devices.

Clarke and Besnoy (2010) carried out a study where Personal Digital Assistants (PDAs) were integrated into two eighth grade social studies classrooms at one school in Highland Heights, USA to create a bridge that connected traditional textbook teaching with new technology. The results revealed that the using of technology in the classroom provided exciting opportunities to capture students' attention in social studies topics. Integrating technology into the classroom can provide a bridge in making students able to control the environment around them, see how what they are doing in the classroom is relevant to their lives, and keep them motivated to learn new content.

Albetar and Alassali (2009) conducted a study aiming at identifying the source of Media within Civic Education and National Education and identifying the role of Media Education presented in dispositions and equipment with the media skills. This was achieved through content analysis for Media sources and its function through finding frequencies and percentages. The results showed that the focus was on readable media sources in Civic Education books for seventh, eights, and ninth grades and visual sources in National Education books for fifth, sixth, and seventh primary grades. The results indicated that the Civic Education and National Education books dealt with Media Education in a non scientific way. Based on this, the two researchers recommended that the curriculum designers should include activities related to scientific education in a scientific way in Civic Education, National Education and other school subjects.

Abu Alsaied (2009) conducted a study to shed light on the media education in the Palestinian universities under the global challenge in applying the comprehensive assessment principles in the productive and educational institutions in order to reach the determined outcomes that would set a guide for the media education in Palestine and to improve the educational and the training process in all its aspects. The Study has concluded that many outcomes including that there is no difference statistically related to the specialized area of study. In addition to the obstacles that face the media education in Palestine represented in the lack of a system to control the assessment in the Palestinian universities, the lack of budgets for media departments and the unavailability of a clear policy for admission. The suggested proposals focused on increasing the studying hours of the English language and the usage of Internet in digital media and the increase of the external exchange of students and paying attention to the media training.

Wan and Gut (2008) conducted a study to describe and understand the roles of media (TV, radio, music, computer, videogames and Internet) and media literacy education in Chinese and American secondary students' lives and their uses of media and what impact that media literacy may have them. Questionnaires about media uses were sent to secondary schools in three cities in China. The results were compared with data drawn from American national studies on adolescents' media uses. The results revealed that media play similar important roles in Chinese and American adolescents' lives, and indicate the importance of media literacy education, a 21st Century skill. The results also revealed that adolescents in both countries spend a great deal of their time using a variety of media on a daily basis. The study 
concluded with suggestions for how to integrate media literacy education into the school curriculum.

\section{Research Methodology}

Since the nature of the research questions, among others, determines the research method or methods to be employed for investigating the problem of interest (Yin, 1994), this study used the quantitative research methodology. Quantitative research helps researchers discover the reactions of many people to a limited set of questions, thus facilitating comparison and statistical aggregation of the data that will result in a broad generalizable set of the findings (Patton, 2002). Creswell (2003:18) argues that following the quantitative methods of inquiry, a researcher "employs strategies of inquiry such as experiments and surveys, and collects data on predetermined instruments that yield statistical data". Surveys are the most widely used method of data collection in educational studies (Fowler, 2013). In this study, the survey was used for gathering knowledge from faculty members about their perceptions towards the importance of media education in building up students' dispositions.

\subsection{Study Sample}

Table 1. Description of the Study Sample.

\begin{tabular}{clll}
\hline Variable & Level & Frequency & Percentage \\
\hline \multicolumn{1}{c}{ Gender } & Male & 184 & $63 \%$ \\
& Female & 68 & $27 \%$ \\
& Total & 252 & $100 \%$ \\
Type of College & natural and applied sciences & 104 & $41.30 \%$ \\
& Humanities & 148 & $58.70 \%$ \\
& Total & 252 & $100 \%$ \\
Years of Experience & $1-5$ & 58 & $23 \%$ \\
& $6-10$ & 102 & $40.50 \%$ \\
& $11-$ and Above & 92 & $36.50 \%$ \\
& Total & 252 & $100 \%$ \\
\hline
\end{tabular}

The study was conducted in semester I of the 2017/2018 academic year at Al al-Bayt University. The study population consisted of all faculty members, 316 male and 88 female. A total of 252 faculty members completed and returned the questionnaires. Table 1 provides descriptive statistics about the faculty participants regarding personal information: gender, type of college, and years of experience, the main independent variables of interest in this study.

\subsection{Study Instrument}

In order to answer the questions concerning the subject of this study, the data were collected 
using a questionnaire, which was developed by the researcher on the basis of review of the previous research. The questionnaire consisted of two parts. The first part includes demographic information of participants, namely, gender, type of college, and years of experience. The second part of the questionnaire comprises 36 items organized into the following three categories. The first category consists of 12 items relating to faculty members' perceptions of the importance of media education in building up students' cognitive dispositions. In the second category, faculty members were asked to respond to 12 items regarding their perceptions of the importance of media education in building up students' affective dispositions. The third category contains 12 items concerning faculty members' perceptions of the importance of media education in building up students' behavioural dispositions.

The questionnaire was presented in both English and Arabic, the participants' mother tongue to ensure that items would be clear to participants. The items were measured on five-point Likert scale with Strongly Agree ranked as 5, Agree ranked as 4, Not Sure ranked as 3, Disagree ranked as 2, and Strongly Disagree ranked as 1.

Face validity and content validity of the questionnaire were determined, using the comments of 10 experts of the field. The experts were requested to review the questionnaire and write their comments about the relevancy, clarity, and simplicity of the items. They were also requested to add new items and/or remove existing ones.

To assess the reliability of questionnaire, test-retest reliability and internal consistency reliability were used. The questionnaire was administered to 20 instructors on two different occasions. Pearson's correlation between the scores on the first and the second testing was used. For internal consistency Cronbach's alpha was used. Table (2) shows the values for Pearson's coefficient and Cronbach's alpha. The values indicated that the questionnaire is sufficiently reliable.

Table 2. Test-retest Reliability and Internal Consistency Reliability

\begin{tabular}{lll}
\hline Domain & Test-retest & Internal Consistency \\
\hline Cognitive Component & 0.87 & 0.84 \\
Affective Component & 0.83 & 0.81 \\
Behavioral Component & 0.85 & 0.88 \\
\hline
\end{tabular}

\section{Study Findings}

In this part, the findings generated from the questionnaires are presented in terms of the research questions of this study. The data were analyzed using SPSS data analytic software. The three scales provided interval data so descriptive statistics were reported for all items as appropriate. Means, and standard deviations were calculated and analyzed for each one of the thirty-six item statements that comprised the first research question. For background categorical variables, tests of significance of differences between means were carried out. 
Independent samples T-test and Analysis of Variance (ANOVA) were used to answer the second research question. The $(\alpha=0.05)$ level of probability was adopted as the criterion of statistical significance.

\subsection{Research Question 1:}

What are the roles of media education in building up the cognitive, affective, and behavioral components of the university students' dispositions from the perceptions of Al al-Bayt University faculty members?

To answer this question, means, standard deviations, ranks, and the level of the role of media education in building up the students' dispositions, for each item and for the domain as a whole were calculated, as shown in Tables (3, 4, and 5). For the interpretation of means, the following statistical criterion using the following equation was utilized:

Group length $=\underline{\text { maximum limit }- \text { minimum limit }}=5-1 / 3=4 / 3=1.33$

number of categories

Based on this, the categories are as follows: from $(1-2.33)$ low, from $(2.34-3.67)$ moderate, and from (3.68 - 5.0) high. Hence, to specify the level of the agreement or disagreement, the overall mean score was categorized into three levels which is low $(\mathrm{M}=1.00-2.33)$, moderate $(\mathrm{M}=2.34-3.67)$ and high $(\mathrm{M}=3.68-5.00)$.

Table 3 shows that the average role of media education in building up the Cognitive Component of the students' dispositions was high for items $(8,2,4,3,4,11,9,10)$ ranked $(1,2,3,4,5,6,7)$ respectively, and was moderate for items $(1,7,6,5,12)$ ranked $(8,9,10,11,12)$ respectively, and was high on the Cognitive Component as a whole. This indicates that media education plays an important role in building up the Cognitive Component of the students' dispositions from $\mathrm{Al}$ al-Bayet University faculty members' points of view.

Table 4 shows that the average role of media education in building the Affective Component of the students' dispositions was high for items $(17,13,21,20,22,14,18,23)$ ranked $(1,2,3,4,5,6,7,8)$ respectively, and was moderate for items $(19,16,15,24)$ ranked $(9,10,11,12)$ respectively, and was generally high on the Affective Component as a whole. This indicates that media education plays an essential role in building up the Affective Component of the students' dispositions from Al al-Bayet University faculty members' points of view.

Table 5 shows that the average role of media education in building the Behavioral Component of the students' dispositions was high for items $(27,32,34,26,29,33)$ ranked $(1,2,3,4,5,6)$ respectively, and was moderate for items $(25,36,30,35,31,28)$ with ranked $(7,8,9,10,11,12)$ respectively, and was generally high on the Behavioral Component as a whole. This indicates that media education plays a significant role in building up the Behavioral Component of the students' dispositions from Al al-Bayet University faculty members' points of view. 


\section{Macrothink}

Table 3. Means, Standard Deviations, Rank, and Level of the Role of Media Education in Building up the Cognitive Component of the Students' Dispositions

\begin{tabular}{|c|c|c|c|c|c|}
\hline Rank & $\begin{array}{l}\text { Item } \\
\text { No. }\end{array}$ & Item & Means & $\begin{array}{l}\text { Standard } \\
\text { Deviation }\end{array}$ & Level \\
\hline 1 & 8 & $\begin{array}{l}\text { Improving } \\
\text { comprehension of modern mass } \\
\text { media techniques. }\end{array}$ & 4.16 & 1.04 & High \\
\hline 2 & 2 & $\begin{array}{l}\text { Enhancing students' understanding } \\
\text { of regional and international issues. }\end{array}$ & 4. 07 & 0.93 & High \\
\hline 3 & 4 & $\begin{array}{l}\text { Helping students } \\
\text { community } \\
\text { culture }\end{array}$ & 3.92 & 1.19 & High \\
\hline 4 & 3 & $\begin{array}{l}\text { Helping students understand many } \\
\text { common concepts such as the } \\
\text { concepts of consultation, } \\
\text { moderation, democracy, human } \\
\text { rights, women's rights, social } \\
\text { justice and social solidarity and } \\
\text { others }\end{array}$ & 3.89 & 1.12 & High \\
\hline 5 & 11 & $\begin{array}{l}\text { Motivate students towards the } \\
\text { practice of self-learning. }\end{array}$ & 3.78 & 1.16 & High \\
\hline 6 & 9 & $\begin{array}{l}\text { Help students acquire higher } \\
\text { thinking skills (critical thinking, } \\
\text { creative thinking, decision making, } \\
\text { and problem solving). }\end{array}$ & 3.76 & 1.21 & High \\
\hline 7 & 10 & $\begin{array}{l}\text { Raising students' awareness of the } \\
\text { danger of fake media. }\end{array}$ & 3.71 & 0.88 & High \\
\hline 8 & 1 & $\begin{array}{l}\text { Helping students understand their } \\
\text { rights and duties and the rights and } \\
\text { duties of others. }\end{array}$ & 3.67 & 1.22 & Moderate \\
\hline 9 & 7 & $\begin{array}{l}\text { Enhancing students' research, } \\
\text { analysis and evaluation skills of } \\
\text { everything presented through the } \\
\text { media. }\end{array}$ & 3.64 & 1.13 & Moderate \\
\hline 10 & 6 & $\begin{array}{l}\text { Protecting students from negative } \\
\text { effects of modernization on their } \\
\text { values, beliefs and local culture. }\end{array}$ & 3.62 & 1.24 & Moderate \\
\hline 11 & 5 & $\begin{array}{l}\text { Helping students link school } \\
\text { subjects to real and current events. }\end{array}$ & 3.59 & 1.26 & Moderate \\
\hline 12 & 12 & $\begin{array}{l}\text { Enhancing students' understanding } \\
\text { of their courses and hence improve } \\
\text { their academic achievement. }\end{array}$ & 3.54 & 1.16 & Moderate \\
\hline \multicolumn{3}{|c|}{ Total Degree of the Cognitive Component } & 3.78 & 0.97 & High \\
\hline
\end{tabular}




\section{Ml Macrothink}

Table 4. Means, Standard Deviations, Rank, and Level of the Role of Media Education in Building up the Affective Component of the Students' Dispositions

\begin{tabular}{|c|c|c|c|c|c|}
\hline Rank & $\begin{array}{c}\text { Item } \\
\text { No. }\end{array}$ & Item & Means & $\begin{array}{l}\text { Standard } \\
\text { Deviation }\end{array}$ & Level \\
\hline 1 & 17 & $\begin{array}{l}\text { Evoking students' sense of the importance of having } \\
\text { the skill to deal with the media. }\end{array}$ & 3.98 & 1.02 & High \\
\hline 2 & 13 & Encouraging cooperation among students. & 3.96 & 1.20 & High \\
\hline 3 & 21 & $\begin{array}{l}\text { Strengthen students' sense of belonging and loyalty } \\
\text { to their country. }\end{array}$ & 3.92 & 1.31 & High \\
\hline 4 & 20 & Maintaining social control among students. & 3.88 & 0.87 & High \\
\hline 5 & 22 & Develop role model university students. & 3.84 & 0.78 & High \\
\hline 6 & 14 & $\begin{array}{l}\text { Helping students get rid of many psychological } \\
\text { problems (such as poor adaptation, shyness, } \\
\text { introversion and selfishness). }\end{array}$ & 3.77 & 1.10 & High \\
\hline 7 & 18 & Enhancing students' self-confidence. & 3.74 & 1.08 & High \\
\hline 8 & 23 & $\begin{array}{l}\text { Promoting positive media values among students } \\
\text { (such as honesty, objectivity, impartiality and public } \\
\text { interest). }\end{array}$ & 3.68 & 1.01 & High \\
\hline 9 & 19 & $\begin{array}{l}\text { Enhancing students' internal locus of control that } \\
\text { makes them responsible for their behaviours. }\end{array}$ & 3.64 & 1.69 & Moderate \\
\hline 10 & 16 & Enhancing students' motivation for learning. & 3.56 & 1.41 & Moderate \\
\hline 11 & 15 & $\begin{array}{l}\text { Fostering students' love of reading and love of } \\
\text { books. }\end{array}$ & 3.48 & 1.21 & Moderate \\
\hline \multirow[t]{2}{*}{12} & 24 & $\begin{array}{l}\text { Improving students' feelings of satisfaction and } \\
\text { conformity with the requirements of university life. }\end{array}$ & 3.24 & 1.64 & Moderate \\
\hline & & Total Degree of the Affective Component & 3.71 & 0.94 & High \\
\hline
\end{tabular}

Table 5. Means, Standard Deviations, Rank, and Level of the Role of Media Education in Building up the Behavioral Component of the Students' Dispositions

\begin{tabular}{|c|c|c|c|c|c|}
\hline Rank & $\begin{array}{l}\text { Item } \\
\text { No. }\end{array}$ & Item & Means & $\begin{array}{l}\text { Standard } \\
\text { Deviation }\end{array}$ & Level \\
\hline 1 & 27 & $\begin{array}{l}\text { Provide students with skills to help them } \\
\text { communicate effectively. }\end{array}$ & 3.98 & 1.02 & High \\
\hline 1 & 32 & $\begin{array}{l}\text { Train students on the mechanisms of information } \\
\text { search, classification, organization, analysis and } \\
\text { interpretation. }\end{array}$ & 3.98 & 1.12 & High \\
\hline 3 & 34 & $\begin{array}{l}\text { Develop students' abilities to provide critical views } \\
\text { of the media content negatively or positively. }\end{array}$ & 3.93 & 0.86 & High \\
\hline 4 & 26 & $\begin{array}{l}\text { Help students combat intellectual deviations } \\
\text { according to the appropriate methods. }\end{array}$ & 3.88 & 0.98 & High \\
\hline 5 & 29 & $\begin{array}{l}\text { Enable students to develop and reform the local } \\
\text { environment, and make people closer to each other. }\end{array}$ & 3.86 & 1.24 & High \\
\hline
\end{tabular}




\begin{tabular}{|c|c|c|c|c|c|}
\hline 6 & 33 & $\begin{array}{l}\text { Enhance students' participation in the planning of } \\
\text { various media activities and programs. }\end{array}$ & 3.69 & 1.28 & High \\
\hline 7 & 25 & Help students face rumours and misinformation. & 3.66 & 0.96 & Moderate \\
\hline 8 & 36 & $\begin{array}{l}\text { Develop students' abilities to produce media content } \\
\text { and communicate it to others. }\end{array}$ & 3.64 & 1.21 & Moderate \\
\hline 9 & 30 & $\begin{array}{l}\text { Enable students to share their visions of university } \\
\text { work at the local and international levels with } \\
\text { students from other universities. }\end{array}$ & 3.52 & 0.89 & Moderate \\
\hline 10 & 35 & $\begin{array}{l}\text { Develop students' ability to make sound choices } \\
\text { about the media. }\end{array}$ & 3.46 & 1.32 & Moderate \\
\hline 11 & 31 & $\begin{array}{l}\text { Encourage students to live with changes in } \\
\text { contemporary society }\end{array}$ & 3.36 & 1.01 & Moderate \\
\hline \multirow[t]{2}{*}{12} & 28 & $\begin{array}{l}\text { Help students in addressing problems related to the } \\
\text { elements of the educational process. }\end{array}$ & 3.28 & 1.12 & Moderate \\
\hline & & Total Degree of the Behavioral Component & 3.68 & 0.96 & High \\
\hline
\end{tabular}

\subsection{Research Question 2:}

Are there any statistically significant differences in the responses of the participants about the roles of media education in building up university students' dispositions due to the variables: gender (male, female), years of experience (less than five years, from five to ten years, more than ten years), and type of college (natural and applied sciences, humanities)?

To answer this question, two types of statistical tests of difference were used: A) Means, standard deviations, and T-tests were used to determine differences in the responses of the participants about the roles of media education in building up university students' dispositions because of the variables: gender (male, female), and type of college (scientific, human). These differences are shown in tables (6 and 7).

Table 6. Means, Standard Deviations, and T- test for the Effect of Gender on the Components of the Students' Dispositions

\begin{tabular}{ccccccc}
\hline Component & Gender & Frequency & Means & $\begin{array}{c}\text { Standard } \\
\text { Deviations }\end{array}$ & (t) Value & $\begin{array}{c}\text { Significance } \\
\text { Level }\end{array}$ \\
\hline Cognitive & Male & 70 & 3.75 & 0.876 & 0.497 & 0.061 \\
& Female & 24 & 3.81 & 1.062 & & \\
Affective & Male & 64 & 3.65 & 0.866 & -1.530 & 0.584 \\
& Female & 25 & 3.77 & 1.013 & & \\
Behavioral & Male & 50 & 3.72 & 0.908 & -0.373 & 0.617 \\
& Female & 19 & 3.64 & 1.012 & & \\
\hline
\end{tabular}

Table 6 shows that there are no statistically significant differences at the level of $(\alpha=0.05)$ in the participants' responses regarding the roles of media education in building up students' dispositions with its three components (Cognitive, Affective, Behavioral) due to the variable of gender. 


\section{Macrothink}

Table 7. Means, Standard Deviations, and T- test for the Effect of Type of College (Scientific, Human) on the Components of the Students' Dispositions

\begin{tabular}{ccccccc}
\hline Component & $\begin{array}{c}\text { Type of } \\
\text { College }\end{array}$ & Frequency & Means & $\begin{array}{c}\text { Standard } \\
\text { Deviations }\end{array}$ & (t) Value & $\begin{array}{c}\text { Significance } \\
\text { Level }\end{array}$ \\
\hline Cognitive & Scientific & 23 & 3.82 & 0.78 & 0.642 & 0.522 \\
& Human & 69 & 3.74 & 1.02 & & \\
Affective & Scientific & 42 & 3.75 & 0.88 & 0.844 & 0.844 \\
& Human & 49 & 3.67 & 0.92 & & \\
Behavioral & Scientific & 39 & 3.65 & 0.91 & 0.980 & 0.980 \\
& Human & 30 & 3.71 & 0.93 & & \\
\hline
\end{tabular}

Table 7 shows that there are no statistically significant differences at the level of $(\alpha=0.05)$ in the participants' responses regarding the roles of media education in building up students' dispositions with its three components (Cognitive, Affective, Behavioral) due to the variable of type of college.

B) Means, standard deviations, and one way ANOVA were used to determine differences in the responses of the participants about the roles of media education in building up university students' dispositions because of the variable: years of experience ( 1 - 5 years, $6-10$ years, 11 years and above). These differences are shown in tables (8 and 9).

Table 8. Means, Standard Deviations, and Frequencies for the Years of Experience Variable on the Components of the Students' Dispositions

\begin{tabular}{ccccc}
\hline Component & $\begin{array}{c}\text { Years of } \\
\text { Experience }\end{array}$ & Frequency & Means & $\begin{array}{c}\text { Standard } \\
\text { Deviations }\end{array}$ \\
\hline \multirow{4}{*}{ Cognitive } & $1-5$ & 16 & 3.94 & 1.16 \\
& $6-10$ & 46 & 3.89 & 0.95 \\
& 11 and Above & 30 & 3.52 & 0.79 \\
& Total & $\mathbf{9 2}$ & $\mathbf{3 . 7 8}$ & $\mathbf{0 . 9 6}$ \\
\hline \multirow{5}{*}{ Affective } & $1-5$ & 20 & 3.79 & 0.68 \\
& $6-10$ & 38 & 3.42 & 0.94 \\
& $11-$ and Above & 32 & 3.93 & 0.92 \\
& Total & $\mathbf{9 0}$ & $\mathbf{3 . 7 1}$ & $\mathbf{0 . 9 1}$ \\
\hline \multirow{5}{*}{ Behavioral } & $1-5$ & 11 & 3.96 & .062 \\
& $6-10$ & 36 & 3.31 & 1.01 \\
& $11-$ and Above & 23 & 3.78 & 0.76 \\
& Total & $\mathbf{7 0}$ & $\mathbf{3 . 6 8}$ & $\mathbf{0 . 9 2}$ \\
\hline
\end{tabular}


Table 9. One-way ANOVA of the Effect of Years of Experience Variable on the Roles of Media Education in Building Up Students' Dispositions on All Components

\begin{tabular}{|c|c|c|c|c|c|c|}
\hline Component & $\begin{array}{c}\text { Source of } \\
\text { variation }\end{array}$ & $\begin{array}{l}\text { Sum of } \\
\text { squares }\end{array}$ & $\begin{array}{c}\text { Degrees of } \\
\text { freedom }\end{array}$ & $\begin{array}{l}\text { Mean } \\
\text { square }\end{array}$ & $\begin{array}{c}\mathrm{F} \\
\text { Statistic }\end{array}$ & Significance \\
\hline \multirow[t]{3}{*}{ Cognitive } & Between groups & 7.963 & 2 & 3.981 & & \\
\hline & Within groups & 204.634 & 89 & 2.299 & 1.731 & $0.012 *$ \\
\hline & Total & 212.597 & 91 & & & \\
\hline \multirow[t]{3}{*}{ Affective } & Between groups & 12.282 & 2 & 6.141 & & \\
\hline & Within groups & 172.806 & 87 & 1.986 & 3.092 & $0.001 *$ \\
\hline & Total & 185.088 & 89 & & & \\
\hline \multirow[t]{3}{*}{ Behavioral } & Between groups & 12.753 & 2 & 6.376 & & \\
\hline & Within groups & 132.275 & 67 & 1.974 & 3.229 & $0.001 *$ \\
\hline & Total & 145.028 & 69 & & & \\
\hline
\end{tabular}

Table 8 shows that there are apparent differences in the means of the participants' responses regarding in the roles of media education in building up students' dispositions with its three components (Cognitive, Affective, and Behavioral) due to the variable of years of experience. In average the mean of the participants' responses with $1-5$ years of experience is the highest (3.90), followed by 11 years and above (3.74), and finally $6-10$ years (3.54). In order to determine whether the differences between the means are significantly statistical differences at the level $(\alpha=0.05)$, a One-way ANOVA was conducted, as shown in table (9).

Table 9 shows that there are statistically significant differences at the level $(\alpha=0.05)$ in the participants' responses regarding the role of media education in building up students' dispositions due to the years of experience variable, and to determine where the significant differences in the means lie, Scheffé post hoc test was used, as shown in table (10).

Table 10. Scheffé test of the Differences in the Means of the Participants' Responses Due to Years of Experience Variable

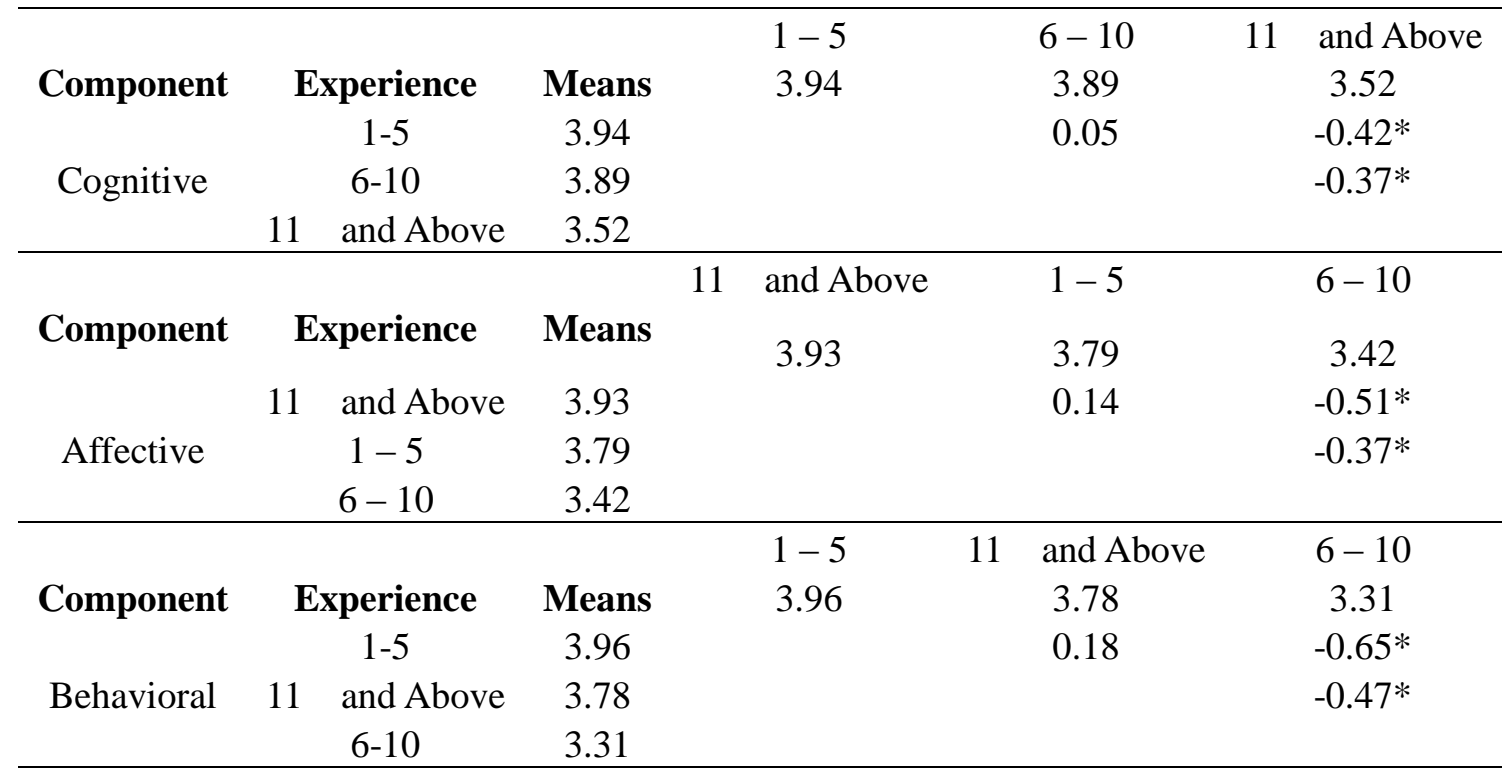


As shown in table 10, Scheffé post hoc test for significance indicates that the difference in the participants' responses regarding the role of media education in building up the cognitive domain of students' dispositions is in favor of $(1-5)$ years and $(6-10)$ years compared to (11 years and above). In both affective and behavioral domains, the difference is in favor of (11 years and above) and $(1-5)$ years compared to $(6-10)$ years.

\section{Discussion and Conclusion}

The results of the first question indicate that media education plays an important role in building up the cognitive, the affective, and the behavioral components of the students' dispositions from Al al-Bayet University faculty members' points of view. The research attributes this result to the fact that the faculty members do realize that the principle goal of the teaching learning process is creating individuals who are capable of dealing with all that surrounds them and meet the demands of life, and hence cope with the rapid changes taking place in all aspects of life. In order to achieve this goal, the teaching and learning process should aim at building the students from all aspects of their personality in a comprehensive, balanced and integrated manner by developing their spiritual, mental, emotional and physical abilities and skills.

Media education, without a doubt, plays a major role in the accomplishment of the ultimate aim of the teaching learning process, particularly so, in the information age. As a major source of modern knowledge and information, media education plays an essential role in the students' cognitive component by improving students' comprehension of modern mass media techniques, enhancing their understanding of regional and international issues, helping them understand community culture and global culture and many common concepts. In addition, media education plays an important role in motivating students towards learning independently, and acquiring higher thinking skills, as well raising their awareness of the dangers of fake news and false information.

With regard to the affective component of students' dispositions, media education plays a major role to help students develop a stable personality and character. It can be especially powerful for students who are not motivated towards study. In this regard, media education helps students evoke a sense of having the skill to deal with the media, encourage cooperation among students, strengthen their sense of belonging and loyalty to their country. Media education also contributes in maintaining social control among students, developing them as role models, helping them get rid of many psychological problems, enhancing their self-confidence, and promoting positive values among them.

Along with the cognitive and affective components, media education plays a significant role in building up the behavioral component of the students' dispositions. It provides students with skills to help them communicate effectively, trains them on the mechanisms of information search, classification, organization, analysis and interpretation, and develop their abilities to provide critical views of the media content negatively or positively. Media education also help students combat intellectual deviations according to the appropriate 
methods, enable them to develop and reform the local environment, and make people closer to each other, and enhance their participation in the planning of various media activities and programs.

The positive perceptions of $\mathrm{Al}$ al-Bayet University faculty members regarding the role of media education in building up the students' dispositions mentally, emotionally and behaviorally, could also be attributed to the fact that universities have been relying on modern multiple media as a main tool that augments the teaching and learning environment. Media education, as such is an effective mean that aids in the personality development of the students as a whole. Media literate students are cognitively, emotionally and behaviorally competent students.

The results of this study agree with those of Tur, Marin and Carpenter (2017); Muhingi et al. (2015); Bani Issa and Al Fawaris (2015); Jia et al. (2015); Jaidori (2014); Duncan et al. (2012) which indicated the significant and influential roles of modern and diverse media in the teaching learning process, and hence in personality development of learners from all dimensions.

The results of the second question indicate that faculty members with teaching experience of $(1-5)$ years and $(6-10)$ years acknowledge more importance of media education for building up the cognitive domain of students' dispositions compared to (11 years and above). This result clearly depicts that as the experience of faculty members increases, their perceptions towards the importance of media education in building up the cognitive domain of students' dispositions seem to decline. This result could be attributed to the fact that faculty members with experience ranging from one to five years, and to a lesser extent six to ten years are more interested in using modern and diverse media in academic work. Therefore, they acknowledge that technology and multimedia applications have a great impact on the students' learning and hence, media education play a major role in the cognitive component of the personality of their students. On the other hand, faculty members who have more than ten years of experience in teaching have reached the notion that caring about their students has greater impact on their educational experiences. Therefore, those faculty members acknowledge the significant role of media education in improving the students' dispositions cognitively, affectively, and behaviorally, but stronger in the latter two components.

The study recommended the need to conduct seminars and workshops for faculty members in universities to clarify the importance of media education and its positive and negative effects on learners. Also, it is recommended to conduct more studies on media education and its impact on teaching learning process in general, and on learners in particular. Finally, it is highly recommended that a course in media education for students should be integrated within the curriculum of $\mathrm{Al}$ al-Bayet University, and all other universities as well.

\section{References}

Abu Alsaied (2009). The Reality of Media Education in The Palestinian Universities in light of the Implementation of the Comprehensive Assessment Applied on the Media 
Departments in the Palestinian Universities in Gaza. Arab Journal for Quality Assurance in Higher Education, 2(3), 37-88.

Al Badrani, F. (n.d.). Media and Digital Education and the Realization of the Knowledge Society. Retrieved from http://www.caus.org.lb/PDF/EmagazineArticles/fadal_mohamad_albadrani_Moustaqbal _\%20Arabi\%20-final.indd.pdf

Albetar, L., \& Alassali, A. (2009). Media Education in the Primary Stage Textbook of Palestinian Curricula: Civic and National Education. A Paper Presented to the Conference: "The 21st Century Educational Process: Reality and Challenges" An-Najah National University, 17-18/10/2009.

Aufderheide, P. (1993). National Leadership Conference on Media Literacy. Conference Report. Washington, DC: Aspen Institute.

Austin E.W., Chen Y.Y., Pinkleton B.E., \& Johnson J.Q. (2006). Benefits and Costs of Cannel one in a Middle School Setting and the Role of Media Literacy Training. Pediatrics, 117(3), 423-33. https://doi.org/10.1542/peds.2005-0953

Baris, M., Fatih \& Tosun, Nilgun. (2013). Can Social Networks and E-Portfolio be Used Together for Enhancing Learning Effects and Attitudes? Turkish Online Journal of Educational Technology - TOJET, 12(2), 51-62.

Bloom, B., S., Max D. E., Edward J. F., Walker H. H., \& David R. K. (1956). Taxonomy of Educational Objective: The Classification of Educational Goals: Handbook 1: Cognitive Domain, David McKay Company, Inc.

Brophy, J. (1999). Perspectives of Classroom Management: Yesterday, Today and Tomorrow. In H. Freiberg (Ed.), Beyond Behaviorism: Changing the Classroom Management Paradigm, 43-56. Boston: Allyn and Bacon.

Buckingham, D. (2003). Media Education: Literacy, Learning and Contemporary Culture. Cambridge: Polity.

Business Dictionary: http://www.businessdictionary.com/definition/media.html

Chu, D., \& Chu, S. (2010). Media Awareness in the Age of New Media: A Case Study of Primary 4 Students in Hong Kong. Proceedings of the American Society for Information Science and Technology, 47(1), 1-9. https://doi.org/10.1002/meet.14504701117

Chu, D., \& Chu, S. (2010). Media Literacy Education in China. Springer Scientific + Business Media: Singapore.

Clarke, L., \& Besnoy, K. (2010). Connecting the Old to the New: What Technology-Crazed Adolescents Tell Us about Teaching Content Area Literacy. Journal of Media Literacy Education, 2(1), 47-56.

Creswell, J. W. (2003). Research design: Qualitative, quantitative, and mixed methods approaches, ( $2^{\text {nd }}$ ed.) Thousand Oaks, California: Sage Publications. 


\section{Ml Macrothink}

Dani, D., Wan, G., \& Henning, J.E. (2010). A Case for Media Literacy in the Context of Socioscientific Issues. New Horizons in Education, 58(3), 85-98.

Dollard, N., Christensen, L., \& Colucci, K. (1996). Constructive Classroom Management. Focus on Exceptional Children, 29(2), 1-12.

Duncan, D., Hoekstra, A., \& Wilcox, B. (2012). Digital Devices, Distraction, and Student Performance: Does In-Class Cell Phone Use Reduce Learning? Astronomy Education Review, 11(1), 1-4. https://doi.org/10.3847/AER2012011

Eshun, I., \& Mensah, M. F. (2013). Domain of Educational Objectives Social Studies Teachers' Questions Emphasis in Senior High Schools in Ghana. Journal of Education and Practice, 4(4), 185-196.

Farrant, J. S. (1980). Principles and Practice of Education. London: Longman Group.

Fedorov, A. (2008). Media Education Around the World: Brief History. Acta Didactica Napocensia, 1(2), 56-68.

Fedorov, A. (2014). Media Education Literacy in the World: Trends. European Researcher, 67(1-2), 176-187. https://doi.org/10.13187/issn.2219-8229

Fortuna, Carolyn. (2015). Digital Media Literacy in a Sports, Popular Culture, and Literature Course. Journal of Media Literacy Education, 6(3), 81-89.

Fowler, F. (2013). Survey research methods (applied social methods) (5 ${ }^{\text {th }}$ ed.). Thousand Oaks, CA: Sage.

Geraee, N., Kaveh, M. H., Shojaeizadeh, D., \& Tabatabaee, H., R. (2015). Impact of Media Literacy Education on Knowledge and Behavioral Intention of Adolescents in Dealing with Media Messages according to Stages of Change. Journal of Advances in Medical Education \& Professionalism, 3(1), 9-14.

Hobbs, R. (2011). What a Difference Ten Years Can Make: Research Possibilities for the Future of Media Literacy Education. Journal of Media Literacy Education, 3(1), 29-31.

Hobbs, R., Donnelly, K., Friesem, J., \& Moen, M. (2013). Learning to Engage: How Positive Attitudes about the News, Media literacy, and Video Production Contribute to Adolescent Civic Engagement. Educational Media International, 50(4), 231-246. https://doi.org/10.1080/09523987.2013.862364

Hussain, I. (2005). A Study of Emerging Technologies and their Impact on Teaching Learning Process. Un-published Ph.D. Thesis, Islamabad: Allama Iqbal Open University, Pakistan.

Hussain, I., \& Safdar, M. (2008). Role of Information Technologies in Teaching Learning Process: Perception of the Faculty. Turkish Online Journal of Distance Education-TOJDE, 9(2), 46-56.

IFTC (International Film and Television Council) (1977). Preface. In International Film and 
Television Council (Ed.), Media Studies in Education (p.3). Paris: UNESCO.

Ismali, N. (2015). The Integration of New Media in Schools: Comparing Policy with Practice. International Education Studies, 8(12), 231-240. https://doi.org/10.5539/ies.v8n12p231

Jaidori, S. (2014). The Impact of Educational Media in The Development of the Performance of Public High School Students, Educationally and culturally: Opinions of a Sample of Students from the city of Damascus. Journal of Al - Quds Open University for Research and Studies, 2(34), 399-427.

Jia, L., Snow, C., \& White, C. (2015). Teen Culture, Technology and Literacy Instruction: Urban Adolescent Students' Perspectives. Canadian Journal of Learning and Technology, 41(3), 1-36.

Jolls, T., \& Wilson, C. (2014). The Core Concepts: Fundamental to Media Literacy Yesterday, Today, and Tomorrow. Journal of Media Literacy Education, 6(2), 68-78. https://doi.org/10.23860/JMLE-2016-06-02-6

Kivunja, C. (2015). Unpacking the Information, Media, and Technology Skills Domain of the New Learning Paradigm. International Journal of Higher Education, 4(1), 166-181. https://doi.org/10.5430/ijhe.v4n1p166

Lee, A. Y. L., \& So, C. Y. K. (2014). Media Literacy and Information Literacy: Similarities and Differences. Comunicar, 42(XX1), 137-145. http://dx.doi.org/10.3916/C42-2014-13

LEE, A., Y. (2010). Media Education: Definitions, Approaches and Development around the Globe. New Horizons in Education, 58(3), 1-13.

Lu, M., Newman, R., \& Miller, M. (2014). Connecting Secondary and Postsecondary Student Social Media Skills: Recommendations for Administrators. Educational Leadership and Administration: Teaching and Program Development, 25(March 2014), 54-64.

Lusted, D. (1991). Introduction. In D. Lusted (Ed.), The Media Studies book: A guide for Teachers (pp.1-11). London: Comedia Book.

Maghazi, A. M. (2015). Including Media Education in Palestinian Curriculum: A Survey Study. Journal of Education, 30(117), 289-338.

Main, R. (1992). Integrating the Affective Domain into the Instructional Design Process. California State University, College of Communications. Brooks AFB, TX: Air Force Systems Command.

Mangal, S. K. (2011). Advanced Educational Psychology, (2 ${ }^{\text {nd }}$ ed.). New Delhi, PHI Learning Private Limited.

Martens, H. (2010). Evaluating Media Literacy Education: Concepts, Theories and Future Directions. Journal of Media Literacy, 2(1), 1-22.

Martin, F. (2006). Ethnography: A Future for Primary Geography and Primary Geography Research? International Research in Geographical and Environmental Education, 14(4), 
364-371. https://doi.org/10.1080/10382040508668372

Media Literacy Week (2017, November). What is Media Education? Medialiteracy.ca (Website for Media Literacy Week). Retrieved October 12, 2010, from: https://www.medialiteracyweek.ca/about/what-is-media-education/

Micklich, D., L. (2011). Examining the Cognitive, Affective, and Psychomotor Dimensions in Management Skill Development through Experiential Learning: Developing a Framework. Developments in Business Simulation and Experiential Learning, 38, 261-272.

Muhingi, W., Mutavi, T., Kokonya, D., Simiyu, V., Musungu, B., Obondo, A., \& Kuria, M. (2015). Social Networks and Students' Performance in Secondary Schools: Lessons from an Open Learning Centre, Kenya. Journal of Education and Practice, 6(21), 171-177.

NAMLE (2010). Media Literacy Defined. Namle.net (website for National Association for media Literacy Education). Retrieved November 12, 2017, from: http://namle.net/publications/media-literacy-definitions

Nitko, A. J., \& Brookhart, S. M. (2001). Educational Assessment of Students, (6 $6^{\text {th }}$ ed.). Boston, MA: Pearson Education Inc.

Ofcom (2010). What is Media Literacy - Ofcom's Definition. Ofcom.org.uk (website for Ofcom). Retrieved November 12, 2017, from: http://stakeholders.ofcom.org.uk/marketdata-research/media-literacy/about/

Patton, M. Q. (2002). Qualitative research and evaluation methods. (3 ${ }^{\text {rd }}$ ed.). Thousand Oaks, California: Sage Publication.

Peifer, Angie (2014). The Purpose of Public Education and the Role of the School Board, National Connection. Retrieved, July, 29,2017 from: http://huffingtonpost.com/heather-wolpertgawron/what-is-the-purpose-of-pu_b_774497. html

Potter WJ. (2008). Media Literacy. (4 ${ }^{\text {th }}$ ed). London: SAGE; 2008.

Prensky, Marc. (2002). The Motivation of Gameplay: The Real Twenty - first Century Learning Revolution. On the Horizon, 10(1), 5-11. https://doi.org/10.1108/10748120210431349

Roberts, D., Foehr, U., \& Rideout, V. (2005, March). Generation M: Media in the Lives of 8-18 Year-Olds. Kaiser Family Foundation. Retrieved November 13, 2017, from: http://www.kff.org/entmedia/7251.cfm

Shamany, S. (2014). Taibah University Role in Forging Students' Dispositions: Taibah University as a Model. Taibah University Journal of Educational Sciences, 9(2), 47-67.

Shomaimari, F. (2010). Media Education: How to deal with media? (1 $1^{\text {st }}$ ed.), King Fahad National Library, Riyadh KSA. 
Thoman, E. (1995). Operational Definitions of Media Literacy. Los Angeles: Center for Media Literacy.

Tur, Marin \& Carpenter (2017). Using Twitter in Higher Education in Spain and the USA. Comunicare: Media Education Research Journal, 51(XXV), 19-27. http://dx.doi.org/10.3916/C51-2017-02.

Ulaş AH., Epçaçan C., \& Koçak B. (2012). The concept of "Media Literacy" and an Evaluation on the Necessity of Media literacy Education in Creating Awareness towards Turkish Language. Procedia-Social and Behavioral Sciences, 31, 376-84. https://doi.org/10.1016/j.sbspro.2011.12.070

Wan, Guofang \& Gut, Dianne. (2008). Roles of Media and Media Literacy Education: Lives of Chinese and American Adolescents. New Horizons in Education, 56(2), 28-42.

Yin, R. (1994). Case study research: Design and methods (2 ${ }^{\text {nd }}$ ed.). Thousand Oaks, California: Sage Publication, Inc.

\section{Copyright Disclaimer}

Copyright for this article is retained by the author(s), with first publication rights granted to the journal.

This is an open-access article distributed under the terms and conditions of the Creative Commons Attribution license (http://creativecommons.org/licenses/by/3.0/). 